\title{
PENGALAMAN MUHAMMADIYAH MEMBUMIKAN NILAI-NILAI PLURALISME
}

\author{
Biyanto \\ IAIN Sunan Ampel, Jl. A. Yani No. 117 Surabaya, \\ mr_abien@yahoo.com
}

\begin{abstract}
This article deals with the issue of religious pluralism in the view of the leading authorities within Muhammadiyah. The paper argues that the scholars of the organization develop a unique view of religious pluralism in line with the vision of the founding fathers. Apart from some "discursive distortion" that these scholars might have undergone in the process of developing the discourse, their view deserves some appreciation for its depth and originality. The paper tries to show that there is indeed a tension between the cadres of the organization on the problem at hand. To dwell into this tension, the paper distinguishes between two major groups within the organization, namely that which accepts the notion of religious pluralism, and that which rejects it. The former includes such well-known scholars as Syafii Maarif, Amin Abdullah, Abdul Munir Mulkhan, and Moeslim Abdurrahman, whereas the latter includes the preachers and mosque-activists. Apart from these two groups, the paper will also look at the particular role that the Muhammadiyah's Youth Movement has played in discourse-development among the members of the organization. Hence, the areas that the paper will cover include those that have been well-represented by the most admitted elements of the organization.
\end{abstract}

Keywords: Pluralism, religiosity, tension, discoursedevelopment.

\section{Pendahuluan}

Di antara tema penting yang banyak diwacanakan pemikir Muslim era kontemporer adalah pluralisme keagamaan (religious pluralism). ${ }^{1}$ Tema ini umumnya dibicarakan dalam konteks hubungan antar-

1 Charles Kurzman, "Pengantar Islam Liberal dan Konteks Islaminya", dalam Charles Kurzman (ed.), Wacana Islam Liberal Pemikiran Islam Kontemporer tentang Isu-isu Global, terj. Bahrul Ulum dan Heri Junaidi (Jakarta: Paramadina, 2003), xlv-lx. 
agama. Dengan pemahaman ini berarti wacana pluralisme keagamaan sesungguhnya telah muncul pada masa awal pertumbuhan Islam, terutama ketika terjadi proses penaklukan (fath.) kaum Muslim terhadap non-Muslim. Interaksi umat Islam pada masa periode itu mendapat legitimasi sharî́ah yang memberikan jaminan hak nonMuslim, terutama para ahli kitab (Yahudi dan Kristen), untuk tetap menjalankan ajaran agama sepanjang mereka memberikan kesetiaan dan membayar upeti pada pemimpin Muslim yang berkuasa.

Realitas sejarah tersebut menunjukkan bahwa sejak awal telah muncul kesadaran di kalangan pemimpin Islam untuk membangun tata kehidupan yang harmonis di atas keragaman kultur, suku, dan agama. Dalam konteks elit agama di Indonesia, wacana pluralisme keagamaan juga banyak dibicarakan. Apalagi Majelis Ulama Indonesia (MUI) dalam Musyawarah Nasional (Munas) yang ke-7 pada 26-29 Juli 2005 telah mengeluarkan fatwa sesat terhadap sekularisme, pluralisme, dan liberalisme. Tiga paham ini dalam perspektif kritikus disebut "sipilis". Pluralisme yang dihukumi sesat oleh MUI adalah paham yang mengajarkan bahwa semua agama sama. ${ }^{2}$ Beberapa tokoh dari organisasi sosial keagamaan pun memberikan respons yang sangat beragam terhadap isu pluralisme keagamaan.

Muhammadiyah sebagai salah satu ormas keagamaan telah menunjukkan respons beragam. Sebagian tokoh Muhammadiyah memberikan apresiasi positif pada pluralisme dan sebagian yang lain menolak. Tokoh seperti Ahmad Syafii Maarif, Amin Abdullah, Abdul Munir Mulkhan, dan Moeslim Abdurrahman, dapat dikatakan mewakili kelompok pemikir Muhammadiyah yang sangat apresiatif terhadap pluralisme. Sementara aktivis Muhammadiyah yang menolak gagasan pluralisme seperti Muhammad Muqodas, Yunahar Ilyas, dan Musthafa Kamal Pasha. Menurut mereka para penolak, ide pluralisme dan liberalisme diaggap bertentangan dengan ajaran Islam. Bahkan wacana pluralisme di kalangan warga Muhammadiyah dianggap sudah sangat meresahkan. ${ }^{3}$ Perbedaan pandangan di kalangan elit ini

\footnotetext{
${ }^{2}$ Budhi Handriyanto, 50 Tokoh Islam Liberal Indonesia (Jakarta: Hujjah Press, 2007), xli-xlii.

3 Yunahar Ilyas, "Pluralisme Agama dalam Perspektif Islam", dalam Syamsul Hidayat dan Sudarno Shobron (eds.), Pemikiran Muhammadiyah: Respons terhadap Liberalisasi Islam (Surakarta: Muhammadiyah University Press, 2005), 283-296. Lihat juga Mushafa Kamal Pasha, "Wacana Pluralisme dan Liberalisasi Agama: Keresahan Warga Muhammadiyah”, dalam Pemikiran Mubammadiyah, 339-357.
} 
menarik dicermati untuk melihat keterlibatan Muhammadiyah dalam membumikan nilai-nilai pluralisme.

\section{Tipologi Pluralisme}

Menurut Kuntowijoyo, pluralisme dapat ditipologikan menjadi dua; pluralisme negatif dan pluralisme positif. ${ }^{4}$ Istilah pluralisme negatif digunakan untuk menunjukkan sikap keberagamaan seseorang yang sangat ekstrim. Sikap ekstrem itu misalnya ditunjukkan dengan mengatakan bahwa beragama itu ibarat memakai baju sehingga ia dapat menggantinya kapan pun dikehendaki. Jadi terdapat pengakuan bahwa ada banyak agama. Secara prinsip pernyataan ini memang sesuai realitas. Tetapi dengan menyatakan bahwa perpindahan agama (konversi) itu wajar terjadi, semudah orang mengganti baju tentu merupakan hal yang dapat menimbulkan kontroversi. Pluralisme disebut negatif jika ada orang berpandangan tidak perlu memegang teguh keyakinan agamanya. Agama itu ibarat baju, yang terpenting adalah iman yang ada dalam dada.

Sementara pluralisme positif merupakan sikap keberagamaan yang sangat mengedepankan penghormatan terhadap pendapat, pilihan hidup, dan keyakinan. Ketika menjelaskan makna pluralisme positif ini, Kuntowijoyo banyak mencontohkan pengalamannya pada saat belajar di luar negeri. Misalnya, ketika ada pengumuman pesta bir maka ia datang dengan membawa coca cola. Jika ada temannya yang ketagihan bir di apartemennya maka ia dapat mengantar ke warung. Bahkan ketika ditanyakan apakah kulkas miliknya dapat digunakan untuk menyimpan bir, ia pun menjawab boleh asal dirinya tidak disuruh minum bir. Ternyata, Amerika yang menurut Kuntowijoyo sangat majemuk juga telah memberikan peluang bagi berkembangnya pluralisme positif. ${ }^{5}$

Sementara itu Nurcholish Madjid (Cak Nur) menekankan bahwa keanekaragaman atau pluralitas dalam pola hidup manusia merupakan kehendak Allah dan fakta alamiah (sunnat Allâh). Dalam hal ini Cak Nur mengungkapkan bahwa pluralisme adalah suatu sistem nilai yang mengharuskan manusia menghormati semua bentuk keanekaragaman dengan menerima hal tersebut sebagai suatu realitas yang sebenarnya dan dengan melakukan semua kebaikan sesuai dengan watak pribadi

\footnotetext{
4 Kuntowijoyo, Muslim Tanpa Masjid: Esai-esai Agama, Budaya, dan Politik dalam Bingkai Strukturalisme Transendental (Bandung: Mizan, 2001), 287.

${ }^{5}$ Ibid., 289.
} 
masing-masing. ${ }^{6}$ Pada konteks ini Cak Nur menganjurkan agar umat Islam menerapkan prinsip kenisbian ke dalam. Prinsip ini oleh Cak Nur disebut dengan relativisme internal (internal relativism). Karakter relativisme internal ini menurut Cak Nur dapat dijadikan jalan keluar agar umat terhindar dari klaim kemutlakan untuk diri sendiri dan kelompok sendiri. Prinsip relativisme internal ini dikemukakan Cak Nur dalam konteks membangun ukhumwah Islâmîah. ${ }^{7}$

Melalui semangat persaudaraan inilah perlu diusahakan untuk mengubah perbedaan menjadi pangkal sikap hidup yang positif, seperti berlomba-lomba menuju kebaikan (al-khayrât). Kondisi ini dapat terwujud jika tumbuh sikap saling menghormati dan menghargai perbedaan di antara warga masyarakat. Menurut Cak Nur, Indonesia dengan jumlah penduduk Muslim terbesar di dunia dapat menawarkan diri menjadi laboratorium untuk mengembangkan toleransi dan pluralisme agama. Apalagi umat Islam Indonesia sedang berusaha keras untuk membawa masuk Islam ke dalam dialog yang positif dan konstruktif dengan berbagai tuntutan tempat dan waktu. ${ }^{8}$ Cak Nur juga menjadikan beberapa ayat al-Qur'ân yang dapat dijadikan dasar membangun nilai-nilai pluralisme. ${ }^{9}$

Hukum perbedaan menurut Cak Nur merupakan ketetapan Tuhan untuk umat manusia. Bahkan hukum perbedaan juga berlaku bagi kaum beriman berdasarkan latar belakang biografi, sosial, dan budaya masing-masing. ${ }^{10}$ Karena itu persaudaraan berdasarkan iman (ukhumwah imânîah) dalam kerangka kemajemukan sangat dianjurkan oleh Allah. ${ }^{11}$ Karena perbedaan itu merupakan ketetapan Tuhan, maka setiap orang harus berusaha dengan bersungguh-sungguh (ijtihâd) dalam mencari, memahami, dan menangkap kebenaran. Cak Nur mengutip pendapat Ibn Taymiyah (wafat 728 H/1328 M) yang menyatakan bahwa mereka yang berijtihad tidak dapat dipersalahkan karena jika ijtihadnya benar ia akan mendapatkan pahala ganda,

\footnotetext{
${ }^{6}$ Nurcholish Madjid, Islam Doktrin dan Peradaban: Sebuab Telaab Kritis tentang Masalah Keimanan Kemanusiaan dan Kemodernan (Jakarta: Paramadina, 1992), lxxv.

7 Nurcholish Madjid, Masyarakat Religius: Membumikan Nilai-nilai Islam dalam Kehidupan Masyarakat (Jakarta: Paramadina, 2000), 41.

8 Nurcholish Madjid, "Mencari Akar-akar Islam Bagi Pluralisme Modern: Pengalaman di Indonesia", dalam Mark R. Woodward (ed.), Jalan Baru Islam: Memetakan Paradigma Mutakbir Islam Indonesia (Bandung: Mizan, 1998), 112-113.

9 al-Qur'ân, 49: 11-13.

${ }_{10}$ Madjid, Masyarakat Religius, 29.

11 al-Qur'ân, 49: 10.
} 
sebaliknya jika salah pun akan tetap mendapatkan pahala meskipun hanya satu. ${ }^{12}$ Karena itu kebebasan berpikir, menyampaikan pendapat, dan berkumpul, tanpa saling curiga antar-kelompok masyarakat harus tetap dijaga.

Ilmuwan yang juga disebut Bapak Perbandingan Agama di Indonesia, Mukti Ali, juga mengajukan tipologi pluralisme keagamaan. Menurut Mukti Ali, pluralitas merupakan realitas yang sangat jelas kelihatan. Di Indonesia pun terdapat banyak agama. Setiap agama mengajarkan jalan hidup yang berbeda-beda dan merupakan ekspresi dari pemeluknya untuk memahami ajaran Tuhan. Karena bangsa Indonesia hidup dalam suasana masyarakat serba jamak (plural society) maka dibutuhkan jalan untuk mencapai kerukunan dalam kehidupan keagamaan.

Mukti Ali menunjukkan beberapa pilihan yang diajukan untuk menumbuhkan nilai-nilai pluralisme. Pertama, pendapat yang menyatakan bahwa semua agama sama. Tipe ini disebut dengan "sinkretisme". Pola sinkretis ini tumbuh subur bukan hanya di Indonesia tapi juga di beberapa negara berkembang lainnya. Di Indonesia, sinkretisme ini menjadi ajaran utama dari kelompok kebatinan. Dalam laporan Badan Kongres Kebatinan Indonesia pada 1959 dikemukakan rumusan yang menyatakan bahwa segala konsepsi tentang Tuhan adalah aspek-aspek dari Ilahi yang satu yang supreme, tidak berkesudahan, kekal, dan segala bentuk agama adalah aspekaspek dari jalan besar menuju kebenaran yang satu. Rumusan ini menunjukkan salah satu pilar dari ajaran kaum sinkretis.

Pola kedua disebut reconception, berarti menyelami dan meninjau kembali agama sendiri dalam konfrontasi dengan agama-agama lain. Pola ini menghendaki agar disusun suatu agama universal yang memenuhi kebutuhan semua orang dan bangsa dengan jalan reconception. Jalan ini ditempuh dengan cara bahwa setiap orang harus tetap menganut agamanya sendiri, tetapi dalam setiap agama tersebut orang harus memasukkan unsur-unsur dari agama lain.

Pola ketiga disebut sintesis, yang berarti menciptakan suatu agama baru yang elemen-elemennya diambilkan dari berbagai agama. Cara ini dilakukan agar setiap pemeluk agama merasa bahwa sebagian dari ajaran agamanya telah terambil dalam agama sintesis itu. Dengan cara ini setiap pemeluk agama berharap dapat menemukan kehidupan yang rukun dan damai.

12 Madjid, Masyarakat Religius, 42. 
Pola keempat disebut pergantian, yang berarti mengakui bahwa agamanya sendiri itulah yang benar, sedangkan agama orang lain adalah salah. Dengan demikian akan ada usaha untuk memasukkan pemeluk agama lain ke dalam agamanya. Ia tidak rela ada orang lain memiliki agama dan kepercayaan yang berbeda. Karena itu, agamaagama lain yang ada harus diganti dengan agama yang ia peluk agar tercipta kerukunan hidup dalam beragama.

Pola kelima disebut agree in disagreement (setuju dalam perbedaan). Pola ini mengajarkan bahwa agama yang ia peluk itulah agama yang paling baik, dan mempersilahkan orang lain untuk mempercayai bahwa agama yang dipeluknya adalah agama yang paling baik. Tipologi ini juga mengajarkan bahwa setiap agama memiliki perbedaan dan persamaan. Maka, sikap yang perlu dikembangkan dalam kaitan ini adalah saling menghargai antar-pemeluk agama. ${ }^{13}$

Dari beberapa alternatif yang ada, Mukti Ali menyatakan bahwa pola agree in disagreement adalah yang paling relevan diaktualisir oleh setiap pemeluk agama. Dikatakannya, orang yang beragama harus percaya bahwa agama yang dipeluk itulah yang paling baik dan paling benar, dan orang lain juga dipersilahkan, bahkan dihargai, untuk mempercayai dan meyakini kebenaran agama yang dianutnya. ${ }^{14}$

Tipologi lain mengenai pluralisme juga dikemukakan Diana L. Eck. Menurutnya, pluralisme keagamaan memiliki empat karakteristik penting: pertama, pluralisme tidak sama dengan diversitas, tetapi merupakan keterlibatan yang energetik dengan keragaman (the energetic engagement with diversity). Diversitas agama adalah sesuatu yang bersifat pemberian (given), sementara pluralisme keagamaan merupakan suatu capaian yang harus senantiasa diusahakan secara aktif (it is an achievement).

Kedua, pluralisme tidak hanya bermakna toleransi, tetapi merupakan pencarian secara aktif guna memahami ragam perbedaan (the active seeking of understanding a cross line of difference). Ketiga, pluralisme tidak sama dengan relativisme, tetapi merupakan usaha untuk menemukan komitmen bersama (the encounter of commitments). Keempat, pluralisme selalu berbasis pada dialog. Dialog berarti keterlibatan dua orang atau lebih untuk berbicara dan mendengar, keduanya berproses

13 A. Mukti Ali, "Ilmu Perbandingan Agama: Dialog, Dakwah, dan Misi", dalam Burhanuddin Daya dan Herman Leonard Beck (eds.), Ilmu Perbandingan Agama di Indonesia dan Belanda (Jakarta: INIS, 1992), 226-229.

${ }^{14}$ Ibid., 230-231. 
untuk membuka pikiran mengenai kesamaan pemahaman dan realitas perbedaan. ${ }^{15}$ Maka, yang dipentingkan dalam dialog ini adalah adanya komitmen dan kesediaan untuk selalu sharing, mengkritik, dan mau dikritik.

\section{Muhammadiyah dan Gagasan Pluralisme}

Salah satu karya penting Muhammadiyah berkaitan dengan gagasan pluralisme adalah buku yang diterbitkan Majelis Tarjih dan Pengembangan Pemikiran Islam yang berjudul Tafsir Tematik al-Qur'an tentang Hubungan Sosial Antarumat Beragama (selanjutnya disebut Tafsir Tematik). ${ }^{16}$ Buku ini bermula dari keinginan Majelis Tarjih dan Pengembangan Pemikiran Islam Pimpinan Pusat Muhammadiyah periode 2000-2005, yang waktu itu dipimpin Amin Abdullah untuk membahas beberapa agenda penting. Di antara persoalan yang diagendakan adalah manhaj tarjih, tuntunan manasik haji, rekonstruksi perjalanan haji nabi, tuntunan bersuci (tahârab), tuntunan ramadhan, tuntunan zakat mal, dan tuntunan al-Qur'ân tematik tentang hubungan antar-umat beragama. ${ }^{17}$

Khusus tuntunan tentang hubungan antar-umat beragama ini Musyawarah Nasional (Munas) Tarjih ke-24 yang berlangsung di Malang pada tanggal 29-31 Januari 2000 mengamanatkan agar disusun pedoman yang bersumber pada al-Qur'ân dengan menggunakan pendekatan tafsir tematik. Melalui pembahasan dalam Munas inilah kemudian disepakati tema yang dibahas perlu diperluas sehingga lahir karya penting tersebut. Sangat disayangkan saat ini buku tersebut tidak dicetak ulang. Hal ini berbeda dengan buku Pedoman Hidup Islami Warga Muhammadiyah, yang laku keras sehingga mengalami proses cetak ulang beberapa kali. Bahkan ada keinginan agar buku kecil produk muktamar ke-44 di Jakarta pada 2000 dapat diterjemahkan dalam berbagai bahasa asing. ${ }^{18}$ Menurut Din Syamsuddin, sesungguhnya sudah ada keinginan untuk menerbitkan kembali buku

${ }^{15}$ Diana L. Eck, "What is Pluralism", Nieman Reports God in the Newsroom Issue, Vol. 47, No. 2 (Summer 1993), 1.

16 Tim Majelis Tarjih dan Pengembangan Pemikiran Islam, Tafsir Tematik al-Qur'an tentang Hubungan Sosial Antarumat Beragama (Yogyakarta: Suara Muhammadiyah, 2000).

17 Pimpinan Pusat Muhammadiyah, "Tanfidz Keputusan Musyawarah Nasional Tarjih”, Berita Resmi Mubammadiyah, No. 02 (Dzulhijjah 1422H/Maret 2002), 127.

18 Pimpinan Pusat Muhammadiyah, Pedoman Hidup Islami Warga Mubammadiyah (Malang: Pimpinan Wilayah Muhammadiyah Jawa Timur dan Universitas Muhammadiyah Malang, 2001). 
Tafsir Tematik dan bahkan untuk mengalihbahasakan dalam edisi Inggris. Tetapi karena ada bagian-bagian yang dianggap belum final, maka harus diselesaikan di internal Muhammadiyah. Masalah yang dianggap belum final itu berkaitan dengan penjelasan mengenai hubungan sosial antar-umat beragama. ${ }^{19}$

Proses cetak ulang buku Tafsir Tematik yang belum kunjung dilaksanakan ini disesalkan oleh banyak aktivis Muhammadiyah. Hal ini karena dalam buku tersebut dihadirkan suatu perspektif yang berbeda dari Muhammadiyah dalam memahami komunitas agama lain. Sebab, seperti dikemukakan Mu'arif, selama ini banyak kalangan menilai bahwa Muhammadiyah cenderung "ke kanan" yang berarti dekat dengan gerakan fundamentalis. ${ }^{20}$ Tentu saja, stigma bahwa Muhammadiyah cenderung "ke kanan" dan berkarakter fundamentalis ini dapat membuat citra yang tidak menguntungkan. Hal ini disebabkan dalam perspektif Barat, fundamentalisme Islam bermakna radikalisme. ${ }^{21}$ Media Barat juga seringkali menggunakan label fundamentalisme kepada hampir semua gerakan keagamaan yang menggunakan kekerasan dalam mencapai tujuannya.

Pada saat ini tema mengenai hubungan sosial antar-umat beragama sedang aktual dibicarakan. Muhammadiyah sebagai salah satu organisasi sosial keagamaan di tanah air jelas harus memberikan kontribusi yang positif. Beberapa fungsionaris Muhammadiyah juga sering dimintai komentar mengenai hubungan antar-umat beragama. Komitmen Muhammadiyah dan tokoh-tokohnya untuk terlibat aktif semakin dituntut seiring dengan berbagai peristiwa yang berkaitan dengan kekerasan sosial atas nama agama yang dilakukan oleh suatu komunitas agama terhadap pemeluk agama yang lain. Dalam konteks inilah beberapa pokok pikiran dalam buku Tafsir Tematik sangat relevan untuk dikembangkan.

19 M. Din Syamsuddin, "Kata Pengantar: Pemikiran Islam Muhammadiyah dalam Pusaran Zaman", dalam Syamsul Hidayat dan Sudarno Shobron (eds.), Pemikiran Muhammadiyab: Respon terhadap Liberalisasi Islam (Surakarta: Muhammadiyah University Press-Universitas Muhammadiyah Surakarta, 2005), vii.

20 Mu'arif, "Dakwah Kultural: Mencermati Kearifan Dakwah Muhammadiyah", dalam Imron Nasri (ed.), Pluralisme dan Liberalisme: Pergolakan Pemikiran Anak Muda Muhammadiyah (Yogyakarta: Citra Karsa Mandiri, 2005), 160.

${ }^{21}$ R. Hrair Dekmejian, "Islamic Revival: Catalyst, Categories, and Consequences", dalam Shireen T. Hunter (ed.), The Politics of Islamic Revivalism: Diversity and Unity (Bloomington: Indiana University Press, 1988), 4-5. 
Secara keseluruhan buku Tafsir Tematik tersebut memuat empat bagian: pertama, prinsip-prinsip hubungan antar-umat beragama, yang di dalamnya dikemukakan tafsir mengenai sejumlah ayat yang dapat dipahami sebagai pengakuan Islam terhadap kenyataan keragaman agama dan bagaimana koeksistensi damai dalam hubungan antar-umat beragama dapat diwujudkan. Bagian kedua, membahas bagaimana seharusnya menjaga hubungan baik dan kerja sama antar-umat beragama. Bagian ketiga, membicarakan deskripsi al-Qur'ân tentang ahli kitab. Bagian keempat, membahas pernikahan beda agama dalam al-Qur'ân. Secara jujur diakui oleh tim penulis buku ini, bahwa empat bagian yang dibicarakan ini memang belum mencakup semua tema yang berkaitan dengan hubungan sosial antar-umat beragama. Tetapi, beberapa wacana yang dikembangkan dalam buku Tafsir Tematik ini harus diapresiasi karena sangat relevan dengan problematika keberagamaan era kontemporer.

Penjelasan konsep tentang pluralisme agama dan respons terhadapnya dibicarakan dalam bagian pertama. Dikatakan bahwa pluralisme dalam kajian teologi memiliki tiga pengertian, yakni: pertama, pluralisme berarti kenyataan bahwa umat beragama itu majemuk. Jadi pluralisme berarti kebhinekaan (actual plurality), seperti yang terjadi di Indonesia yang mengakui banyak agama. Kedua, pluralisme berkonotasi politik yang maknanya sinonim dengan sekularisme. Dalam hal ini sekularisme dapat diartikan dengan dua pengertian; (1) memisahkan agama dari urusan publik dan sekaligus mencerminkan fenomena antiagama, dan (2) negara tidak mengidentifikasikan diri pada agama tertentu, tetapi menghormati dan memberikan kesempatan semua agama untuk berkembang. Kebijakan pemerintah Indonesia terhadap eksistensi agama-agama merupakan cermin berkembangnya sekularisme dalam pengertian yang kedua. Ketiga, pengertian pluralisme merujuk pada suatu pandangan yang menyatakan bahwa semua agama pada akhirnya menuju pada satu kebenaran yang sama. ${ }^{22}$

Buku Tafsir Tematik juga mengungkapkan bahwa dalam tradisi Islam terdapat beberapa indikator (qarinah) yang menunjukkan pengakuan terhadap orang lain agama (the religious other). Di antaranya adalah adanya pernyataan dalam Piagam Madinah (al-Mîthâq alMadinah) yang menyatakan bahwa konsep umat meliputi komunitas Islam dan non-Islam. Pada pasal 25 dari Piagam Madinah dikatakan:

22 Tim Majelis Tarjih dan Pengembangan Pemikiran Islam, Tafsir Tematik, 19. 


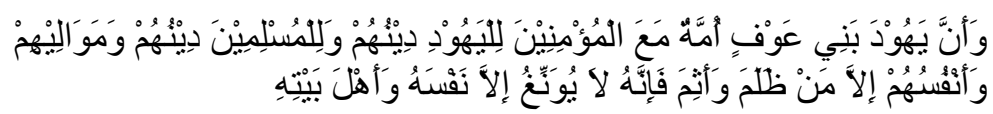

Bahwa orang-orang Yahudi Bani 'Awf adalah satu bangsa (umat) bersama orang-orang Mukmin. Kaum Yahudi bebas memeluk agama mereka dan kaum Muslim juga bebas memeluk agama mereka. Ketentuan ini juga berlaku bagi pengikut dan sekutu mereka serta diri mereka sendiri. Kecuali bagi orang yang zalim dan berbuat kejahatan, maka ia tidak lain hanya membawa keburukan atas dirinya dan keluarganya. ${ }^{23}$

Pernyataan dalam Piagam Madinah tersebut jelas menunjukkan bahwa Islam memiliki pengalaman sejarah untuk menerapkan nilainilai pluralisme keagamaan. Hebatnya, pengalaman ini telah muncul pada masa awal sejarah perkembangan Islam. Dikatakan dalam buku Tafsir Tematik ini, bahwa pasal-pasal dalam Piagam Madinah setidaknya telah menunjukkan bahwa Nabi Muhammad dan para sahabat telah mengaktualisir nilai-nilai pluralisme dalam pengertian pluralisme realistik (actual pluralism). ${ }^{24}$ Sayang sekali wacana pluralisme keagamaan yang digulirkan buku Tafsir Tematik belum mendapat tempat yang memadai di kalangan aktivis Muhammadiyah.

Melalui publikasi di majalah Tabligh yang diterbitkan Majelis Tabligh dan Dakwah Khusus (MTDK) Pimpinan Pusat Muhammadiyah, wacana pluralisme keagamaan dikritik habis-habisan. Beberapa tulisan di majalah ini menempatkan pluralisme sebagai paham yang sesat karena dianggap mengajarkan penyatuan agama. ${ }^{25}$ Sekularisme, pluralisme, dan liberalisme, yang sering disingkat dengan istilah "sipilis," sama-sama dianggap merusak aqidah umat Islam pada umumnya dan secara khusus paham keagamaan Muhammadiyah. Paham sipilis juga disebut sebagai virus liberal yang berbahaya di Muhammadiyah. ${ }^{26}$

Elit Muhammadiyah, Yunahar Ilyas, misalnya berpandangan bahwa sekularisme, pluralisme, dan liberalisme bertentangan dengan Islam. Sekularisme yang dimaksud adalah paham yang mengajarkan pemisahan agama dan negara (pengalaman keagamaan dan

23 Muhammad 'Abd. al-Mâlik b. Hishâm al-Mu'âfirî, al-Sîrah al-Nabawîyah, Vol. 1-2 (t.t.: Dâr al-Turâth al-'Arabî li al-Tibâ'ah wa al-Nashr, t.th.), 353.

${ }^{24}$ Tim Majelis Tarjih dan Pengembangan Pemikiran Islam, Tafsir Tematik, 24.

25 Nuim Hidayat, "Sesat: Penyamaan Semua Agama", Tabligh, Vol. 01, No. 08 (Maret 2003), 47-49.

${ }^{26}$ Fakhrurrozi Reno Sutan, "Virus Liberalis di Muhammadiyah", Tabligh, Vol. 02, No. 08 (Maret 2004), 14-15. 
pengalaman hidup). Dijelaskan oleh Yunahar, bahwa Islam merupakan agama yang mengajarkan seluruh aspek kehidupan. Bahkan menurut rumusan Matan Keyakinan dan Cita-cita Hidup Muhammadiyah (MKCHM) dikatakan bahwa agama Islam memiliki empat aspek ajaran yakni aqidah, ibadah, akhlaq, dan mu'amalah dunyawryah. ${ }^{27}$ Dengan pemahaman ini berarti seharusnya tidak ada lagi dikotomi urusan agama dan non-agama. Sebab, urusan agama dan non-agama dapat berjalan bersama. Bahkan agama dapat menjadi dasar dalam berbuat sehingga dinilai sebagai ibadah dalam pandangan Allah. ${ }^{28}$

Terhadap masalah pluralisme, Yunahar menyatakan bahwa pluralisme yang bertentangan dengan Islam adalah paham yang mengajarkan kebenaran semua agama. Yunahar kemudian meminjam istilah Kuntowijoyo untuk menyatakan bahwa bentuk pluralisme yang demikian disebut sebagai pluralisme negatif. ${ }^{29}$ Menurut Yunahar, doktrin ajaran Islam telah mengajarkan bahwa Islam merupakan satusatunya agama yang diridhai oleh Allah swt. ${ }^{30}$ Ini berarti agama lain yang dianut oleh sebagian umat manusia ditolak kebenarannya. Yunahar menekankan bahwa yang ditolak dari agama selain Islam adalah kebenarannya, bukan keberadaannya. ${ }^{31}$

Berkaitan dengan keberadaan agama lain, Islam mengajarkan tidak menolak karena memang tidak ada paksaan untuk memeluk agama Allah. Dalam hal ini Islam membebaskan pada manusia untuk memilih agama selain Islam dengan konsekuensi bahwa di akhirat nanti ia akan digolongkan sebagai orang yang merugi. Islam juga mengajarkan sikap saling menghargai dan toleran (tasâmụ̣) terhadap pemeluk agama lain, tanpa ada kompromi sedikit pun dalam hal keyakinan. Inilah ajaran yang menurut Yunahar disebut sebagai pluralisme positif. ${ }^{32}$

\footnotetext{
27 Anonim, "Delapan Karakteristik Islam yang Bertentangan dengan Sekularisme, Pluralisme, dan Liberalisme Agama”, Tabligh, Vol. 03, No. 08 (Juni 2005), 62.

28 Anonim, "Sekularisme, Pluralisme, dan Liberalisme Agama Bertentangan dengan Islam", Tabligh, Vol. 03, No. 08 (Juni 2005), 60-65.

${ }^{29}$ Kuntowijoyo, Muslim Tanpa Masjid, 287-289.

30 al-Qur'ân, 5: 3.

31 Yunahar Ilyas, Cakrawala al-Qur'an (Yogyakarta: Suara Muhammadiyah, 2003), 47.

32 Anonim, "Muhammadiyah Tidak Akan Menjadi Organisasi Liberalis", Tabligh, Vol. 03, No. 09 (Juli 2005), 37.
} 


\section{Membumikan Nilai Pluralisme}

Di luar kesan cenderung "ke kanan" atau fundamentalis, sejatinya Muhammadiyah dengan semua kekuatan amal usaha yang dimiliki sangat berkepentingan menghadirkan corak keberagamaan yang moderat. Kesadaran ini muncul dan dapat diamati melalui kiprah Muhammadiyah dalam beberapa tahun terakhir. Pada Sidang Tanwir di Yogyakarta, tanggal 26-29 April 2007, dibicarakan beberapa persoalan yang berkaitan dengan peran kebangsaan Muhammadiyah, termasuk kontribusi yang diberikan dalam membangun kultur demokrasi, hak asasi manusia, lingkungan, dan pluralitas budaya.

Menurut Malik Fajar, Muhammadiyah sesungguhnya telah memiliki rujukan normatif untuk memberikan arahan terhadap warganya agar dapat menjalani kehidupan dalam lingkungan geografis dan budaya yang pluralistik. ${ }^{33}$ Landasan yang dimaksud Malik Fajar adalah buku pintar yang dapat dijadikan petunjuk pelaksanaan dan petunjuk teknis dalam menjalani hidup. Buku yang dimaksud Malik Fajar adalah Pedoman Hidup Islami Warga Muhammadiyah. Buku ini telah banyak menguraikan bahasan tentang kehidupan berkeluarga, bermasyarakat, berbangsa dan bernegara, melestarikan lingkungan, serta kehidupan dalam seni dan budaya.

Sementara, Sudibyo Markus menyatakan bahwa peran kebangsaan Muhammadiyah sesungguhnya dapat diamati sejak organisasi ini didirikan. Banyak program dan kegiatan Muhammadiyah telah diarahkan di bidang dakwah, pendidikan, kesejahteraan sosial, yang secara langsung bersentuhan dengan kehidupan bermasyarakat, berbangsa, dan bernegara. ${ }^{34}$ Meski Alwi Shihab dalam penelitiannya menyatakan bahwa salah satu faktor kelahiran Muhammadiyah adalah untuk membendung arus kristenisasi, namun ini bukan berarti Muhammadiyah tidak menghargai keragaman agama dan budaya. Berbagai dialog keagamaan yang dilakukan Ahmad Dahlan dengan sejumlah misionaris Kristen menunjukkan komitmen dari the founding fathers Muhammadiyah untuk membangun hubungan antar-agama yang lebih dialogis.

33 Abdul Malik Fajar, "Muhammadiyah: Peran Kebangsaan, Dinamika Perkembangan Demokrasi, HAM, Lingkungan, dan Pluralitas Budaya", dalam Materi Tanwir Muhammadiyah (26-29 April 2007), 87-90.

34 Sudibyo Markus, "Peran Kebangsaan Muhammadiyah dan Dinamika Perkembangan Demokrasi, HAM, Lingkungan, dan Pluralitas Budaya", dalam Materi Tanwir Tanwir Muhammadiyah (26-29 April 2007), 91. 
Bukan hanya pergaulan lintas agama, Muhammadiyah sejak awal juga sudah menunjukkan sebagai organisasi yang sangat terbuka. Hubungan Muhammadiyah dengan Budi Utomo, suatu organisasi yang menurut M. T. Arifin disebut berideologi "nasionalisme-Jawa", 35 menunjukkan sifat keterbukaan itu. Hubungan baik dengan Budi Utomo juga ditunjukkan melalui kesediaan organisasi ini mengundang Ahmad Dahlan untuk menyampaikan ceramah di depan peserta kongres pada 1917. Peserta Kongres Budi Utomo sangat tertarik dengan ceramah Ahmad Dahlan sehingga beberapa di antara mereka memintanya untuk memberikan pengajian sekaligus membuka cabang Muhammadiyah di daerahnya. Karena itu tidak mengherankan jika pada 1920, Muhammadiyah telah berhasil mengembangkan sayap hingga ke seantero Jawa. ${ }^{36}$

Selain membangun hubungan baik dengan organisasi keagamaan seperti Sarekat Islam, Muhammadiyah juga sangat terbuka dengan organisasi non-keagamaan. Bahkan dengan organisasi non-keagamaan seperti ISDV (Indische Social Demochratische Vereeniging) yang berhaluan komunis pun Muhammadiyah juga membangun hubungan baik. Hal ini dibuktikan dengan undangan Ahmad Dahlan pada tokoh ISDV seperti Semaun, Darsono, dan Baars, untuk berbicara dalam Rapat Terbuka Muhammadiyah yang berlangsung di Kauman. ${ }^{37}$ Beberapa fakta yang dipaparkan tersebut menunjukkan keinginan Muhammadiyah untuk mengembangkan kultur dialog lintas agama dan etnis. Sekali lagi, ini menunjukkan karakter Muhammadiyah yang sangat terbuka dengan keragaman.

Saat ini Muhammadiyah dengan amal usaha yang dimiliki juga berusaha keras untuk mengembangkan kultur keterbukaan. Semangat keterbukaan Muhammadiyah tentu akan sangat berarti bagi warganya, terutama mereka yang berada di daerah minoritas. Sudibyo Markus menceritakan bahwa ada beberapa sekolah Muhammadiyah di daerah mayoritas Kristen, seperti di Nusa Tenggara Timur, justru memiliki banyak murid beragama Kristen. Hal ini kemudian menimbulkan guyonan di kalangan warga persyarikatan bahwa "ada banyak pastor alumni sekolah Muhammadiyah." Bahkan UMK yang semestinya singkatan dari Universitas Muhammadiyah Kupang, dipelesetkan

\footnotetext{
35 M. T. Arifin, Muhammadiyah Potret yang Berubah (Surakarta: Institut Gelanggang Pemikiran Filsafat, Sosial Budaya, dan Kependidikan, 1990), 21.

36 Ibid., 23.

${ }^{37}$ Ibid.
} 
dengan "Universitas Muhammadiyah Kristen" karena memiliki 75 persen mahasiswa yang beragama Kristen. ${ }^{38}$ Fenomena ini menunjukkan jati diri Muhammadiyah yang meski bercirikan Islam tetapi memiliki kepedulian yang sangat besar yang diwujudkan melalui sikap menghargai keragaman budaya dan kepercayaan masyarakat.

Usaha untuk membangun hubungan lintas agama, etnik, dan kultur, juga terus dilakukan Muhammadiyah hingga kini. Kepeloporan Muhammadiyah dalam berbagai forum multikultur bertaraf internasional, seperti World Peace Forum (WPF), Asian Committee on Religions and Peace (ACRP), dan World Committee on Religions and Peace (WCRP), menunjukkan adanya keinginan yang kuat untuk membumikan nilai-nilai pluralisme. Din Syamsuddin sebagai Ketua Umum Pimpinan Pusat Muhammadiyah sekaligus presiden WPF, ACRP, dan WCRP menyatakan bahwa beberapa lembaga tersebut beranggotakan orang-orang terkemuka dari unsur pemimpin, pemikir, elit keagamaan, dan sarjana dari penjuru dunia. ${ }^{39}$

Secara berkala Muhammadiyah dan WPF setiap tahun juga mengadakan sejumlah kegiatan. Salah satunya adalah kegiatan yang dilaksanakan pada Agustus 2006, dengan mengusung tema one bumanity, one destiny, one responsibility. Tema ini dipilih untuk merespons keadaan dunia yang dihantui peperangan, konflik, dan kekerasan. Pada 2012 diadakan pertemuan WPF yang keempat dengan mengambil tema consolidating multicultural democracy. ${ }^{40}$ Pertemuan yang juga diikuti Presiden Susilo Bambang Yudhoyono (SBY) ini menekankan pentingnya kiprah Muhammadiyah dalam melakukan konsolidasi demokrasi multikultural sehingga tercipta hubungan dialogis lintas etnis, budaya, dan agama.

Untuk membangun daya kritis kaum muda, Pimpinan Pusat Muhammadiyah juga pernah memfasilitasi pendirian Pusat Studi Agama dan Peradaban (PSAP). Lembaga ini dipimpin oleh Sukidi, salah satu intelektual muda yang sangat produktif. Di samping sebagai pusat kajian, PSAP juga pernah menerbitkan Jurnal Tanwir yang memuat pikiran-pikiran kaum muda Muhammadiyah progresif. Sayang sekali jurnal ini tidak berumur panjang. Hingga kini, PSAP

${ }^{38}$ Sudibyo Markus, Peran Kebangsaan, 92.

39 Rizal Sukma, et al., Report World Peace Forum: One Humanity, One Desnity, One Responsibility (Jakarta: Bureau for International and Cooperation Central Board of Muhammadiyah, 2006), 1.

${ }^{40}$ Muslim, "Konsolidasi Demokrasi Multikultural”, Majalah Matan, Vol. 77

(Desember 2012), 27. 
masih konsisten melakukan kajian dan publikasi ilmiah dengan tema kehidupan sosial keagamaan yang pluralis dan multikulturalis.

Di samping PSAP juga muncul banyak lembaga yang menjadi wadah berinteraksi kaum muda Muhammadiyah untuk mewacanakan pluralisme, seperti Maarif Institute, Jaringan Intelektual Muda Muhammadiyah (JIMM), al-Maun Foundation, dan Center for Dialogue and Cooperation among Civilisation (CDCC). Maarif Institute dapat dikatakan embrio dari hampir seluruh Non Government Organisation (NGO) berbasis kaum muda Muhammadiyah. Maarif Institute didirikan pada 2002, semasa Syafii Maarif menjadi Ketua Pimpinan Pusat Muhammadiyah. Selain Syafii Maarif, terdapat beberapa figur popular yang tercatat sebagai pendiri Maarif Institute, seperti Haedar Nashir, Moeslim Abdurrahman, Jeffrie Geofannie, Rizal Sukma, dan Suyoto. Di dalam statuta pendirian dikatakan bahwa Maarif Institute berkomitmen pada gerakan kebudayaan dalam konteks keislaman, kemanusiaan, dan keindonesiaan. Beberapa isu kontemporer berkaitan dengan kompleksitas masalah kemanusiaan, seperti HAM, pluralisme, gender, serta dialog antar-agama dan peradaban, telah dijadikan sebagai cakupan persoalan yang memerlukan komitmen dan perhatian bersama.

Hingga kini, Maarif Institute banyak menekuni berbagai kegiatan seminar, workshop, penelitian, dan publikasi. Beberapa tema yang diusung di antaranya Muhammadiyah dan kebangsaan; ${ }^{41}$ pendidikan agama berwawasan $\mathrm{HAM}^{42}$ Islam, good governance, dan kemiskinan; ${ }^{43}$ Untuk mengomunikasikan berbagai hasil kegiatannya, Maarif Institue telah menerbitkan Jurnal Maarif: Arus Pemikiran Islam dan Sosial. Beberapa kegiatan yang telah diadakan merupakan hasil kerja sama Maarif Institute dengan The Asia Foundation (TAF) dan Ford Foundation.

NGO berbasis kaum muda Muhammadiyah yang juga banyak dibicarakan adalah JIMM. Secara organisatoris JIMM dipimpin oleh beberapa orang presidium yang mewakili daerah masing-masing. Di

\footnotetext{
41 Fajar Riza Ul Haq, "Muhammadiyah dan Modernitas Kolonial: Resistensi dan Siasat Politik Kebudayaan", Maarif: Arus Pemikiran Islam dan Sosial, Vol. 1, No. 1 (2003), 11-19. Lihat juga Roeslan Abdulgani, "Kehadiran Muhammadiyah dalam Bangsa Ini”, Maarif: Arus Pemikiran Islam dan Sosial, Vol. 1, No. 1 (2003), 3-10.

42 Fariz, "Pendidikan Agama Berwawasan HAM", Maarif: Arus Pemikiran Islam dan Sosial, Vol. 2, No. 5 (Juli 2007), 28-30.

43 Anonim, "Sinergi Kekuatan untuk Pengentasan Kemiskinan", Maarif: Arus Pemikiran Islam dan Sosial, Vol. 2, No. 6 (Desember 2007), 47-48.
} 
beberapa daerah juga bermunculan lembaga yang berkomitmen melakukan kegiatan pencerahan pemikiran, kerja-kerja intelektual, dan berkhidmat di bidang kemanusian. Misalnya, Center for Religious and Social Studies (ReSIST) di Malang dan Lembaga Kajian Agama dan Sosial (LKAS) di Surabaya.

Bukan hanya di level organisasi dan kaum muda, beberapa Perguruan Tinggi Muhammadiyah, seperti Universitas Muhammadiyah Surakarta (UMS), Universitas Muhammadiyah Yogyakarta (UMY), dan Universitas Muhammadiyah Malang (UMM), juga memiliki komitmen untuk membangun pola kehidupan yang pluralis. Di UMS, melalui lembaga Pusat Studi Budaya dan Perubahan Sosial (PSB-PS), telah dilakukan berbagai kegiatan untuk menumbuhkan pola keberagamaan yang lebih ramah terhadap seni dan budaya. Kegiatan ini dapat dimaknai sebagai upaya menghilangkan stigma bahwa Muhammadiyah anti-budaya lokal.

Pada periode 2000-2006, PSB-PS UMS secara rutin telah menyelenggarakan kegiatan Halaqah Tarjih. Beberapa dari kegiatan halaqah (diskusi) ini dilakukan bekerja sama dengan Majelis Tarjih Pimpinan Pusat Muhammadiyah dan The Ford Foundation. Tema yang diusung dalam kegiatan ini adalah agama dan pluralitas budaya lokal, apresiasi Islam terhadap pluralisme, menuju Muslim berwawasan multikultural, serta Islam dan dakwah kultural. Untuk menumbuhkan kesadaran warga Muhammadiyah terhadap seni dan budaya lokal, PSB-PS juga telah beberapa kali mengadakan kegiatan Pendidikan Apresiasi Seni (PAS).

Kegiatan PAS dirintis sejak 2002, bekerja sama dengan The Ford Foundation dan beberapa sekolah dasar di Surakarta. Pihak yang juga dilibatkan dalam program PAS ini adalah Dinas Pendidikan Surakarta, Majelis Pendidikan Dasar dan Menengah (Dikdasmen) PDM Surakarta, Majelis Dikdasmen PDM Karanganyar, dan beberapa sekolah dasar Islam di Surakarta. Pelibatan sekolah dasar Islam dalam program PAS dimaksudkan untuk menumbuhkan apresiasi terhadap kemajemukan budaya lokal sekaligus wahana penyemaian sikap toleran di kalangan siswa. Untuk memperluas jangkauan program PAS juga pernah dilaksanakan di Padang, Sumatera Barat. ${ }^{44}$

Pada 2002, PSB-PS mendapat kehormatan untuk menyelesaikan konsep dakwah kultural Muhammadiyah. Seperti diketahui, dakwah

44 Anonim, "PAS Periode II: Penyemaian Toleransi dan Apresiasi terhadap Kemajemukan Seni Budaya Lokal”, Kalimatun Sawa', Vol. 01, No. 02 (2004), 32. 
kultural Muhammadiyah merupakan salah satu rekomendasi dari Sidang Tanwir Muhammadiyah di Bali pada 24-27 Januari 2002. Tim PSB-PS yang dipimpin Zakiyuddin Baidhawy bekerja keras selama tiga bulan penuh untuk menyempurnakan naskah. Hingga akhirnya terwujud naskah akademik dakwah kultural yang kemudian dibahas dalam Sidang Tanwir Muhammadiyah di Makasar pada 26-29 Juni 2003. ${ }^{45}$ Naskah penyempurnaan dari tim PSB-PS dengan beberapa masukan dalam Sidang Tanwir di Makasar itulah yang kemudian diterbitkan oleh Pimpinan Pusat Muhammadiyah dalam bentuk buku.

Pada 2003, PSB-PS UMS menyelenggarakan kegiatan Launching dan Bedah Buku Halaqah Tarjih dan Buletin Kalimatun Sawa'. Kegiatan ini menghadirkan Moeslim Abdurrahman, A. Charis Zubair (Universitas Gajah Mada), serta M. Thoyibi dan M. A. Fatah Santoso (PSB-PS). Buku yang dibahas adalah Agama dan Pluralitas Budaya Lokal, Sinergi Agama dan Budaya Lokal: Dialektika Mubammadiyah dan Seni Lokal (2003). Buku ini juga merupakan hasil kegiatan Halaqah Tarjih dalam rangka mengembangkan wacana dialektika agama dan pluralitas budaya lokal.

Kegiatan Halaqah Tarjih kembali dilaksanakan pada 2005. Kegiatan ini merupakan hasil kerjasama PSPB-PS dengan Majelis Tarjih Pimpinan Pusat Muhammadiyah dan The Ford Foundation. Di forum ini dibicarakan berbagai persoalan seperti; (1) akar teologi Islam dan relasinya terhadap multikulturalisme dalam upaya membangun sikap Muslim multikulturalis, (2) menemukan kembali khazanah syariah yang berwajah multikultural, dan (3) melacak konteks sejarah relasi Islam dan multikulturalisme. Narasumber yang dihadirkan saat itu adalah Moeslim Abdurrahman, Haidar Baqir, Achmad Jainuri, Mulyadi Kartanegara, Syamsu Rizal Panggabean, Fathurrahman Jamil, Zuly Qodir, Muhammad Azhar, dan Zakiyuddin Baidhawy. Berbagai pokok pikiran yang berkembang dalam forum Halaqah Tarjih ini kemudian diterbitkan dalam bentuk buku dengan judul Reinvensi Islam Multikultural (2005). ${ }^{46}$

Pada 2007, PSB-PS bekerjasama dengan The Ford Foundation juga menyelenggarakan kegiatan Halaqah Budaya bertema Memaknai Kembali Indonesia: Ikbtiar Menuju Masyarakat Multikultural Berkeadaban

\footnotetext{
45 Anonim, "Bekerja Tiga Bulan Penuh: Tim PSB-PS Selesaikan Penyempurnaan Konsep Dakwah Kultural”, Kalimatun Sawa', Vol. 01, No. 02 (2004), 31.

${ }^{46}$ Zakiyuddin Baidhawy dan M. Thoyibi (ed), Reinvensi Islam Multikultural (Surakarta: PSB-PS UMM, 2005).
} 
dan Berkeadilan. Kegiatan ini dilaksanakan pada 5-7 Agustus 2007 di Surakarta dan sekaligus untuk menyemarakkan perayaan agustusan. Dalam acara ini Din Syamsuddin berkenan hadir dan memberikan keynote speech. Selain diikuti pimpinan Muhammadiyah se-Jawa, acara tersebut juga dihadiri komunitas agama Kristen dan Hindu. Dari pihak Kristen yang turut hadir adalah Djaka Sutapa (Universitas Kristen Duta Wacana, Yogyakarta) dan Haryatmoko. Sementara dari unsur Hindu turut hadir, Nyoman S. Pendit (penulis dan budayawan).

Beberapa kegiatan yang dilaksanakan PSB-PS tersebut merupakan bagian dari usaha untuk mencairkan kebekuan (ortodoksi) pemahaman keagamaan Muhammadiyah karena dirasa belum menunjukkan apresiasi yang memuaskan terhadap wacana dialektika agama dan pluralitas budaya. Kehadiran PSB-PS diharapkan dapat memfasilitasi pertarungan dan pergumulan identitas keagamaan Muhammadiyah dalam bingkai pluralisme dan multikulturalisme. Ditegaskan Yayah Khisbiyah, bahwa dengan cara ini maka usaha untuk menstimulasi agama sebagai gerakan sosial yang membebaskan dan mencerahkan akan dapat ditampilkan Muhammadiyah. ${ }^{47}$ Itu menunjukkan bahwa ada keinginan kuat di kalangan kaum muda untuk menghadirkan ragam kegiatan yang bertujuan membangun kultur pluralis dan multikulturalis.

Usaha untuk menumbuhkan wawasan kebangsaan juga dilakukan Lembaga Penelitian dan Pengembangan Pendidikan Universitas Muhammadiyah Yogyakarta (LP3-UMY) bekerja sama dengan The Asia Foundation (TAF). Program yang dilakukan adalah penyusunan dan pembelajaran buku ajar Civic Education untuk SMA dan yang sederajat. Program ini mulai dirintis sejak 2001 dan hingga kini sudah sampai pada tahap pembelajaran di sekolah. Banyak tema yang diwacanakan dalam buku Civic Education ini seperti konstitusi dan perundang-undangan, demokrasi, HAM, gender, pluralisme, multikulturalisme, dan civil society.

Sementara di UMM juga dikembangkan banyak kegiatan kajian keislaman dan filsafat melalui lembaga Pusat Studi Islam dan Filsafat (PSIF). Penggerak kegiatan PSIF adalah Syamsul Arifin dan Pradana Boy, dua figur yang menonjol dalam pengembangan intelektualitas dan publikasi ilmiah di UMM. Selain di UMS, UMY, dan UMM, beberapa perguruan tinggi Muhammadiyah juga menunjukkan geliat untuk membangun arus keberagamaan yang moderat. Salah satunya

${ }^{47}$ Yayah Khisbiyah, Wawancara, Jakarta, 27 Agustus 2007. 
adalah Universitas Muhammadiyah Sidoarjo (UMSIDA). Dalam mewacanakan beberapa tema sosial keagamaan, Umsida menerbitkan tabloid bernama Khazanah. Melalui Tabloid Khazanah inilah, tema seperti Muhammadiyah dan Islam liberal banyak dibicarakan. ${ }^{48} \mathrm{Di}$ samping itu tema seputar pluralisme dan multikulturalisme juga banyak diwacanakan melalui publikasi majalah komunitas yang dimiliki Muhammadiyah, misalnya melalui majalah Suara Mubammadiyah (diterbitkan Pimpinan Pusat Muhammadiyah) dan Majalah Matan (diterbitkan Pimpinan Wilayah Muhammadiyah Jawa Timur). Wacana yang dikemukakan melalui majalah ini terasa efektif karena memiliki jangkauan yang luas dan penerbitannya pun dilakukan secara berkala.

\section{Penutup}

Berbagai kegiatan yang dilakukan tokoh-tokoh Muhammadiyah, baik kaum tua maupun kaum muda, menunjukkan komitmen untuk menghadirkan wajah Islam moderat dan ramah terhadap keanekaragaman agama dan kultur. Selain melalui kiprah tokoh-tokoh Muhammadiyah, ikhtiar untuk membumikan nilai-nilai pluralisme juga dilakukan amal usaha bidang pendidikan. Lembaga pendidikan Muhammadiyah mulai tingkat dasar, menengah, hingga pendidikan tinggi, telah dimaksimalkan perannya sebagai layanan publik untuk mendidik anak-anak bangsa dari berbagai etnis, golongan, dan agama. Kiprah Muhammadiyah bidang ini kian terasa di daerah-daerah yang berpenduduk minoritas Muslim. Dengan demikian berarti Muhammadiyah telah memberikan respons yang serius terhadap tantangan kehidupan yang semakin plural dan multikultural.

Upaya Muhammadiyah untuk membumikan nilai-nilai pluralisme dengan mengajak funding agencies asing memang sempat memunculkan respons negatif dari kalangan internal dan eksternal. Namun, berbagai kritik tersebut tidak mengurangi keinginan Muhammadiyah untuk tetap mengembangkan nilai-nilai pluralisme dalam kehidupan seharihari. Bahkan kini Muhammadiyah semakin mengintensifkan kegiatannya dengan mengajak sebanyak mungkin individu, masyarakat, lembaga, untuk bersama-sama menghadirkan Islam yang moderat dan berkemajuan. Semua itu menunjukkan bahwa Muhammadiyah ingin menjadi bagian yang tidak terpisahkan dari

48 Syafiq A. Mughni, "Muhammadiyah dan Islam Liberal”, Tabloid Khazanah, No. 15, th. IX, Smt. 1 (2007), 7. 
elemen civil society yang berkeinginan untuk membumikan nilai-nilai pluralisme.

\section{Daftar Rujukan}

Abdulgani, Roeslan. "Kehadiran Muhammadiyah dalam Bangsa Ini", Maarif: Arus Pemikiran Islam dan Sosial, Vol. 1, No. 1, 2003.

Ali, A. Mukti. "Ilmu Perbandingan Agama: Dialog, Dakwah, dan Misi", dalam Burhanuddin Daya dan Herman Leonard Beck (eds.), Ilmu Perbandingan Agama di Indonesia dan Belanda,. Jakarta: INIS, 1992.

Anonim. "Bekerja Tiga Bulan Penuh: Tim PSB-PS Selesaikan Penyempurnaan Konsep Dakwah Kultural, Kalimatun Sawa', Vol. 01, No. 02, 2004.

-----. "Delapan Karakteristik Islam yang Bertentangan dengan Sekularisme, Pluralisme, dan Liberalisme Agama", Tabligh, Vol. 03, No. 08, Juni 2005.

"Muhammadiyah Tidak Akan Menjadi Organisasi Liberalis", Tabligh, Vol. 03, No. 09, Juli 2005.

"PAS Periode II: Penyemaian Toleransi dan Apresiasi terhadap Kemajemukan Seni Budaya Lokal”, Kalimatun Sawa', Vol. 01, No. 02, 2004.

"Sekularisme, Pluralisme, dan Liberalisme Agama Bertentangan dengan Islam", Tabligh, Vol. 03, No. 08, Juni 2005.

-----. "Sinergi Kekuatan untuk Pengentasan Kemiskinan", Maarif: Arus Pemikiran Islam dan Sosial, Vol. 2, No. 6, Desember 2007.

Arifin, M. T. Mubammadiyah Potret yang Berubah. Surakarta: Institut Gelanggang Pemikiran Filsafat, Sosial Budaya, dan Kependidikan, 1990.

Baidhawy, Zakiyuddin dan Thoyibi M. (ed). Reinvensi Islam Multikultural. Surakarta: PSB-PS UMM, 2005.

Dekmejian, R. Hrair. "Islamic Revival: Catalyst, Categories, and Consequences", dalam Shireen T. Hunter (ed.), The Politics of Islamic Revivalism: Diversity and Unity. Bloomington: Indiana University Press, 1988.

Eck, Diana L. "What is Pluralism", Nieman Reports God in the Newsroom Issue, Vol. XLVII, No. 2, Summer 1993. 
Fajar, Abdul Malik. "Muhammadiyah: Peran Kebangsaan, Dinamika Perkembangan Demokrasi, HAM, Lingkungan, dan Pluralitas Budaya", dalam Materi Tanwir Muhammadiyah, 26-29 April 2007.

Fariz. "Pendidikan Agama Berwawasan HAM", Maarif: Arus Pemikiran Islam dan Sosial, Vol. 2, No. 5, Juli 2007.

Handriyanto, Budhi. 50 Tokoh Islam Liberal Indonesia. Jakarta: Hujjah Press, 2007.

Haq, Fajar Riza Ul. "Muhammadiyah dan Modernitas Kolonial: Resistensi dan Siasat Politik Kebudayaan", Maarif: Arus Pemikiran Islam dan Sosial, Vol. 1, No. 1, 2003.

Hidayat, Nuim. "Sesat: Penyamaan Semua Agama", Tabligh, Vol. 01, No. 08, Maret 2003.

Ilyas, Yunahar. "Pluralisme Agama dalam Perspektif Islam", dalam Syamsul Hidayat dan Sudarno Shobron (eds.), Pemikiran Mubammadiyah: Respon terhadap Liberalisasi Islam. Surakarta: Muhammadiyah University Press, 2005.

----. Cakrawala al-Qur'an. Yogyakarta: Suara Muhammadiyah, 2003.

Khisbiyah, Yayah. Wawancara. Jakarta, 27 Agustus 2007.

Kuntowijoyo. Muslim Tanpa Masjid: Esai-esai Agama, Budaya, dan Politik dalam Bingkeai Strukturalisme Transendental. Bandung: Mizan, 2001.

Kurzman, Charles. "Pengantar Islam Liberal dan Konteks Islaminya", dalam Charles Kurzman (ed), Wacana Islam Liberal Pemikiran Islam Kontemporer tentang Isu-isu Global, terj. Bahrul Ulum dan Heri Junaidi. Jakarta: Paramadina, 2003.

Madjid, Nurcholish. "Mencari Akar-akar Islam Bagi Pluralisme Modern: Pengalaman di Indonesia", dalam Mark R. Woodward (ed.). Jalan Baru Islam: Memetakan Paradigma Mutakhir Islam Indonesia. Bandung: Mizan, 1998.

-----. Islam Doktrin dan Peradaban: Sebuah Telaah Kritis tentang Masalah Keimanan Kemanusiaan dan Kemodernan. Jakarta: Paramadina, 1992.

-----. Masyarakat Religius: Membumikan Nilai-nilai Islam dalam Kehidupan Masyarakat. Jakarta: Paramadina, 2000.

Majelis Tarjih dan Pengembangan Pemikiran Islam, Tafsir Tematik alQur'an tentang Hubungan Sosial Antarumat Beragama. Yogyakarta: Suara Muhammadiyah, 2000. 
Markus, Sudibyo. "Peran Kebangsaan Muhammadiyah dan Dinamika Perkembangan Demokrasi, HAM, Lingkungan, dan Pluralitas Budaya, dalam Materi Tanwir Mubammadiyah, 26-29 April 2007.

Mu'âfirî (al), Muhammad 'Abd. al-Mâlik b. Hishâm. al-Sîrah alNabawîyah, Vol. 1-2. t.t.: Dâr al-Turâth al-'Arabî li al-Ṭibâ'ah wa al-Nashr, t.th.

Mu'arif. "Dakwah Kultural: Mencermati Kearifan Dakwah Muhammadiyah", dalam Imron Nasri (ed.), Pluralisme dan Liberalisme: Pergolakan Pemikiran Anak Muda Mubammadiyah. Yogyakarta: Citra Karsa Mandiri, 2005.

Mughni, Syafiq A. "Muhammadiyah dan Islam Liberal", Tabloid Khazanah, No. 15, th. 9, Smt. 1, 2007.

Muhammadiyah, Pimpinan Pusat "Tanfidz Keputusan Musyawarah Nasional Tarjih", Berita Resmi Mubammadiyah, No. 02, Dzulhijjah 1422H/Maret 2002.

Pedoman Hidup Islami Warga Mubammadiyah. Malang: Pimpinan Wilayah Muhammadiyah Jawa Timur dan Universitas Muhammadiyah Malang, 2001.

Muslim. "Konsolidasi Demokrasi Multikultural", Majalah Matan, Vol. 77, Desember 2012.

Pasha, Mushafa Kamal. "Wacana Pluralisme dan Liberalisasi Agama: Keresahan Warga Muhammadiyah", dalam Syamsul Hidayat dan Sudarno Shobron (eds.), Pemikiran Mubammadiyah: Respon terbadap Liberalisasi Islam. Surakarta: Muhammadiyah University Press, 2005.

Sukma, Rizal, et al. Report World Peace Forum: One Humanity, One Desnity, One Responsibility. Jakarta: Bureau for International and Cooperation Central Board of Muhammadiyah, 2006.

Sutan, Fakhrurrozi Reno. "Virus Liberalis di Muhammadiyah", Tabligh, Vol. 02, No. 08, Maret 2004.

Syamsuddin, M. Din. "Kata Pengantar: Pemikiran Islam Muhammadiyah dalam Pusaran Zaman", dalam Syamsul Hidayat dan Sudarno Shobron (eds.), Pemikiran Mubammadiyah: Respon terhadap Liberalisasi Islam. Surakarta: Muhammadiyah University Press-Universitas Muhammadiyah Surakarta, 2005. 